\title{
創薬のためのドッキング法
}

\author{
平山令明
}

\section{Docking Method for Drug Discovery}

\author{
Noriaki HIRAYAMA \\ Basic Medical Science and Molecular Medicine, Tokai University School of Medicine, \\ 143 Shimokasuya, Isehara City 259-1143, Japan
}

(Received July 31, 2006)

\begin{abstract}
The effective integration of detailed structural information with computational chemistry, medicinal chemistry, and informatics transforms the dream of virtual screening into reality. One of the most important technologies essential for virtual screening is an effective docking method to find molecules that efficaciously interact with their target molecules. Since an efficient docking method can be a powerful tool for virtual screening, many different approaches to solving docking problems have been proposed. Docking problems have not yet been solved and none of the currently available programs are perfect in predicting all possible scenarios. Despite the limits and imperfections of the methodology, currently available docking methods are very useful for drug discovery. The basic principles and limits of docking methods together with matters for attention in applying the methods are described in this paper.
\end{abstract}

Key words_ - docking; protein-drug interaction; drug discovery; in silico screening

\section{1. 序論}

多くの疾病は特定の蛋白質の作用と密接に関連し ている．そうした蛋白質は医薬分子の標的になるこ とから，ここでは標的分子と呼ぶことにする．標的 分子の機能を制御するのが医薬分子である．標的分 子の立体構造と機能の仕組みが理解できれば，医薬 分子を合理的に探索することが可能になる．標的分 子の構造と機能を明確に意識して行う医薬分子探索 の方法は英語で structure-based drug design（略し て SBDD）と呼ばれる。適当な日本語訳がないの で，以下 SBDD と呼ぶことにする。

ゲノム解析による疾病関連遺伝子の同定が実用レ ベルになり，かつその遺伝子がコードする標的分子 の発現と構造解析が容易になった現在，これまで SBDD の適用を阻んできた大きな障壁は実質的に 取り除かれようとしている. SBDD が提唱された 20 年前には，コンピュータの能力とコストがもう 1 つの重大な問題であったが，この問題も現在ではほ

東海大学医学部医学科基礎医学系分子生命科学（干259

-1143 伊勢原市下糟屋 143)

e-mail: hirayama@is.icc.u-tokai.ac.jp

本総説は, 日本薬学会第 126 年会シンポジウム S31 で 発表したものを中心に記述したものである.
とんど解消されている，研究資金が豊富にある医薬 専業企業でのみ SBDD は行えるという時代は既に 過去の話になったとも言える，また，医薬分子の研 究開発費が年々巨額化する中で, 上流の研究の効率 化を一段と進める上でも SBDDへの期待は非常に 大きい。 さらに，稀少疾患に関連する疾病遺伝子の 解析が, 特にアカデミアの中で進む中で, アカデミ アを中心とした創薬研究が今正に現実化しょうとし ているが，資金不足のアカデミアで現実的な創薬研 究を展開する上で, SBDDの活用は必須とも言え る.

SBDD にはいくつかのアプローチがあるが，疾 病と直接的に関係する標的分子と候補医薬分子の結 合性を主として分子力場法を用いた理論計算で予測 する手法はドッキング法と呼ばれる，日本語に適当 な訳がないので，以降このままドッキング法と呼ぶ ことにする.ドッキング法の適用は，標的分子の立 体構造が求められていることが前提条件であり，標 的分子の立体構造を強く意識しながら医薬候補分子 を探索する方法である。ドッキング法は，標的分子 と医薬候補分子（以下リガンド分子と呼ぶ）の相互 作用を原子レベルで取り扱う。したがって，その成 果を視覚的に理解することが容易であるという大き 
な魅力がある.

本稿では，ドッキング法の概要，適用する上での 注意点, 実際の適用例そして最後に問題点について 述べることにする。

\section{2. ドッキング法の概要}

この節では，簡単にドッキング法の概要を述べ る.ドッキングはおおむね次の 6 段階の操作で行う のが一般的である。

第一段階 : 標的分子構造の原子座標の準備 多 くの研究者は X 線結晶解析で得られた原子座標を 用いる. NMR 解析で得られた座標やホモロジー・ モデリングなどのモデリング法で得られた座標を用 いてもよい。しかし, 座標の精度が X 線解析で得 られたものよりかなり劣るので，結果の信頼性もま た一般に低いと予想される。本稿では，すべて X 線結晶解析の結果を用いることを前提とする.

第二段階：標的分子中の水素原子位置の推定 $\mathrm{X}$ 線解析は精密な構造解析の手段であるが，多く の限界も持っている。，一番大きな限界は水素原子の 位置が X 線解析では求められないことである。低 分子有機化合物の場合，結晶が良好であれば，何と か求めることができるが，蛋白質 X 線解析では全 く不可能と考えてよい. しかしドッキング法を適用 する場合には，水素原子の位置に関する情報は不可 欠である，そこで，まず水素原子の位置を求める.

多くの水素原子の位置は隣接する非水素原子の位置 に基づいて幾何学的に計算できるが，ヒドロキシル 基などの水素原子の位置は, 幾何学的な計算では求 められないので，まず適当な位置に水素原子を結合 させ，その水素原子の最適な位置をあとで述べる構 造最適化の方法で求める。分子力場法の限界で，構 造最適化は初期に仮定した水素原子の位置に大きく 影響されるので，最適な水素原子が求められたかど うかは何らかの手段で確認しておく必要がある.

第三段階：リガンド分子の結合部位の決定＼cjkstart適 当なリガンド分子と標的分子の複合体結晶の解析が 行われている場合には，結合部位が既に分かってい るので，その情報を活用する．もしアポ蛋白質の構 造解析しかない場合には，結合部位を推定しなけれ ばならない.リガンド分子が結合する部位を予測す る手法は色々提案されているが，医薬分子としての 適性を具えた化合物の結合部位を高い確率で予測で きる方法が筆者らによって最近提案されている.1
しかし，多くのドッキング計算では標的分子とリガ ンド分子の複合体の X 線解析から決定した結合位 置を使用している.

第四段階：リガンド分子の立体配座の推定 標 的分子に結合するときに，リガンド分子がどのよう な立体配座を取るかをドッキング前にあらかじめ予 測することは困難である。リガンド分子は標的分子 に結合したときに非常に不安定な立体配座を取るこ とはできないが，標的分子と結合することである程 度安定化できるので，最安定な立体配座を取る必要 はない。実際に複合体結晶中でリガンド分子が取る 立体配座は最安定な立体配座ではない。筆者らは， 後述するようにリガンド分子が取り得る立体配座を あらかじめ発生させ，それをデータベース化する方 法を取っている。このときの大きな問題点は，必要 な立体配座が本当に発生できているかということで ある。

第五段階：標的分子とリガンド分子の複合体構造 の最適化 標的分子の結合部位にリガンド分子を 配置し, 結合部位で最適になるリガンド分子の構造 を求める．現在，最適化はもつぱら分子力場計算で 行われる，例えば，標的分子とリガンド分子間の相 互作用エネルギーとリガンド分子のひずみエネル ギーを極小化することで, 複合体構造の最適化が行 われる。分子間相互作用は静電相互作用エネル ギー，ファン・デル・ワールスカ及び水素結合エネ ルギーなどで表現される。この段階が文字通りドッ キングである。もし，結合部位との相互作用が不利 であれば，そのリガンド分子はその結合部位に結合 できないことになる，実際に結合部位に収まりきら ない分子をドッキングさせると，その分子は結合部 位から吐き出されてしまう。この最適化の過程で, リガンド分子だけでなく，標的分子の構造も同時に 最適化することも行われる。

第六段階：ドッキング結果の評価＼cjkstart標的分子と リガンド分子の親和性は，これらの分子の結合に伴 う自由エネルギー変化を正確に計算できれば容易に 求めることができる。しかしエントロピー項の計算 が事実上できないこと，分子力場の計算に用いるポ テンシャル関数の不正確さ，水や対イオンの影響が 見積もれないことなどにより，正確に自由エネル ギーを求めることができない。したがって，種々の 評価関数（例えば水素結合の本数）などがドッキン 
グのアルゴリズム毎に用意されており，ドッキング 計算の結果を評価するのに使用される，例えば複数 のリガンド分子とのドッキング計算に基づき，その 中から最も結合性の高いリガンド分子を選択する場 合に，この評価関数で判断する．後述するように, 筆者らはもつぱらリガンド分子のひずみも含めた相 互作用エネルギーのみで結果を判断している.

ドッキングを行うソフトウェアは種々開発されて いる。代表的なものに，DOCK, ${ }^{2)}$ FLExX, ${ }^{3)}$ AutoDock, ${ }^{4)}$ GOLD, 5) GLIDE6) 及び Ph4Dock ${ }^{7)}$ な どがある。それぞれのソフトウェアは各々特徴を持 つている，後述するように，ドッキング計算は，使 用する標的分子の構造の正確さに大きく依存する. しかし，適切な系に対して十分注意して計算を行う と, 十分 in vitro 実験に匹敵する良好な結果が得ら れる。

\section{3. 標的分子構造の評価}

ドッキングでは実験的に決定された標的分子の構 造を用いる。しかし，X 線解析の結果には多くの 偶然誤差と系統誤差が入っているので，原子パラ メー夕（原子座標と後述する原子変位パラメータ及 び占有率を含めたもの）の取り扱いには十分な注意 が必要である．水素原子の問題については既に触れ たので，ここでは割愛する．X線解析は確かに厳 密な方法であるが，蛋白質結晶の本質的な問題によ り，有機低分子結晶の場合に比較して原子パラメー 夕の精度が非常に悪い。

蛋白質結晶には多くの水が含まれている，40 か ら $60 \%$ もの水が蛋白質結晶に含まれるが，回折 X 線により位置が確定できる水分子はごく少数であ る。つまり残りの水は，明確に回折 X 線に反映は せず，漫然とした誤差を全原子の原子パラメータに 与えることになる。 また分子表面にある蛋白質の原 子は大きな運動性を持っていることが多く，蛋白質 結晶のすべての単位胞中で同じ立体配座を取ってい ることはないと推定される。こうした条件は，蛋白 質結晶からの X 線回折を劣化させる。具体的に は，細かい距離の情報を与えるはずの回折角度の大 きい回折 X 線がほとんどゼロになってしまう。こ れは測定できる回折 X 線の数が劇的に少なくなる ことを意味する．この 2 つの悪条件の結果，蛋白質 結晶から得られる回折 X 線の分解能はせいぜいよ くて $1.5 \AA$ ということになる。この数字を文字通り
解釈すると，炭素原子間の単結合と二重結合の判定 ができないことになる。実際に，もしアミノ酸やリ ガンド分子の化学構造が既知でなければ，こうした 結合の差を実験的に決定することは非常に困難であ る。また X 線解析では結晶中の電子密度の分布を 求め, その密度の差によって原子種の判定が本来行 えるはずであるが，蛋白質 $\mathrm{X}$ 線解析で得られる電 子密度は誤差を多く含むために，その客観的な解釈 は困難である。酸素原子と窒素原子の電子数の差は 1 個しかなく，状況によっては両者を判別すること はできない，実際に，多くの解析結果でグルタミン やアスパラギン側鎖の酸素原子と窒素原子の帰属は 不確かである。電子密度と結合距離 $(\mathrm{C}=\mathrm{O}$ と $\mathrm{C}-\mathrm{N})$ からはX 線解析でこれらの原子種を確実に帰属す ることはできない，多くの解析では，周囲の状況を 考慮し，水素結合の形成の予測から原子種の帰属を しているが，確証がある訳ではない。

結晶中と言えども原子は熱振動している．X 線 解析では各原子の座標だけではなく，この運動性も 同時に決定する。この運動性は温度とともに大きく なることから通常温度因子と呼ばれるが，原子変位 パラメータ（atomic displacement parameter）と呼 ぶ方が適切である。本稿ではこれまでの呼び方に従 つて温度因子と呼ぶ，有機低分子化合物の場合，室 温程度で回折 $\mathrm{X}$ 線を測定すると，炭素原子の温度 因子はおおよそ $5 \AA^{2}$ 程度になる。しかし，良好な データに基づいて精密化された蛋白質結晶中でも炭 素原子の温度因子は $10 \AA^{2}$ 以上になる。 その原子が どの結晶単位胞の中でも同じ位置にあれば，その原 子の占有率 (occupancy) は 1.0 となるが，原子が 複数の位置に乱れて存在する（このことを disorder と呼ぶ）と，原子の占有率は 1.0 以下になる。仮に 占有率が 0.5 になることは，酸素原子の場合，電子 の数がその位置に 4 個しかないことになり，先に述 ベたように，回折データに入り込んでくる誤差をあ わせて考えると，その原子の帰属がかなり危ういこ とが分かるであろう。さらに温度因子と占有率は高 い相関を持っている，例えば温度因子が $20 \AA^{2}$ で占 有率が 0.5 である原子は，占有率を 1.0 にすると温 度因子はずっと大きくなる。 また $80 \AA^{2}$ など温度因 子が極端に大きい場合，仮に占有率が 1.0 と帰属さ れていてもその原子種と位置の不確定性は非常に高 い. 現状のドッキングでは原子の熱振動は考慮しな 
いが，可能な限り正確な座標を採用するためには， 座標だけではなく温度因子と占有率も十分に考慮す べきである，特に結合部位にある原子の温度因子が 異常に高いかあるいは原子の占有率が異常に低い場 合には要注意である。

蛋白質の $\mathrm{X}$ 線解析では非常に多くの原子情報が 得られるので，解析者が特に興味を持った部位以外 については，それらの情報の 1 つ 1 つについてその 内容を詳細に検討することはあまりされない，有機 低分子の X 線解析では，各原子座標の標準偏差を 正確に算出するので，標準偏差が大きい部分や標準 偏差から著しくずれた構造を発見し，考察すること ができるが，蛋白質 X 線解析では，ほとんどの解 析で標準偏差は算出されないので，このような考察 は行われないのが通常である，その代わり，主鎖の 立体配座を視覚的に表現した Ramachandran Plot $^{8}$ などを用いて，構造全体の妥当性を議論することが 多い。しかし，ドッキング計算においては，水素原 子の位置まで考慮した構造を扱うため，局所的な構 造の妥当性については X 線解析者以上に神経を尖 らせて吟味すべきである。

標的分子の選択に幅がある場合には，上記のよう な点に留意して，最も適切な標的分子構造を用いる ことが重要である。いずれにしても，X 線解析で 得られた構造を盲目的に信じるのではなく，分子間 相互作用，立体配座，温度因子及び占有率などを総 合的に判断して，その構造の妥当性を吟味すべきで ある。こうした観点からは，分解能が良好で， $R$ 因 子の小さい解析結果を活用することが望ましいが, これらの指数もけっして構造の高質性を $100 \%$ 保証 するものではないことを明記しておく。

ドッキングでは，リガンド分子と標的分子の相互 作用を原子レベルで議論する。したがって，各原子 の位置がごの程度正確であるかをあらかじめ知って おくことは極めて重要である．蛋白質結晶の回折能 の低さにより，十分な数の観測值を得ることができ ないので，多くの蛋白質 $\mathrm{X}$ 線解析では原子座標の 標準偏差（誤差）は算出されない。したがって，多 くの蛋白質 $\mathrm{X}$ 線結晶解析では各原子の不確定性 (誤差) は分からない。これは，特にドッキング法 を適用する場合にはかなり深刻な問題になる。

蛋白質結晶解析において，どの程度の誤差を座標 は含むものかを初めて検討したのが Cruickshank ${ }^{91}$
で，その式をより実用的な問題に適用できるように 変形したのが Blow ${ }^{10)}$ である。詳細 ${ }^{11)}$ は省くが, Blow によって提案されている式は次のようなもの である。

$$
\sigma\left(r, B_{\text {avg }}\right)=2.2 N_{\text {atoms }}^{1 / 2} V_{a}^{1 / 3} n_{\text {obs }}^{-5 / 6} R_{\text {free }}
$$

この式で， $B_{\text {avg }}$ は X 線解析から求められた温度 因子 $B$ の平均值， $N_{\text {atoms }}$ は規則的な構造を持った溶 媒原子を含む占有率が 1.0 の原子の数， $V_{a}$ は結晶 の非対称単位の体積， $n_{o b s}$ は測定した回折 $\mathrm{X}$ 線の 数そして $R_{\text {free }}$ は結晶解析の確かさを表す指数であ る。これらの值は Protein Data Bank ${ }^{12)}$ に供託され た大抵のデータの中に含まれるか，容易にそれらの 情報から計算することができる，左辺の $\sigma\left(r, B_{\text {avg }}\right)$ は $B_{a v g}$ を持った構造における原子の位置の誤差を 示す。この式で求められる原子位置の精度の目安は,

Fig. 1 から簡単に知ることができる. 分解能が 2.0 $\AA$ で $R_{\text {free }}$ が 0.20 を与える標準的な解析例では，位 置の誤差は 0.2 A と見積もることができる。つまり， $0.20 \AA$ 程度のずれでは誤差範囲ということにな る。もちろん，この式で計算される值は，溶媒分子 を含んだ占有率が 1.0 の全原子に対する平均的な值 であるので，原子の存在する場所（特に分子表面か 分子内部か）によって誤差の大きさは変化する.

従来，こうした座標誤差を見積もるために Luzzati プロット13)が用いられてきたが，Cruickshanck はそれが不適切であることを指摘している。現状で

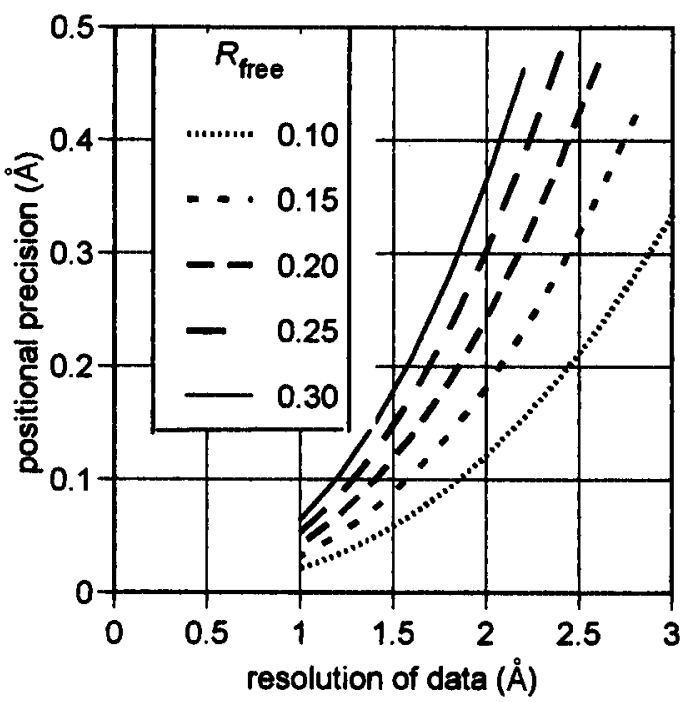

Fig. 1. Rough Guide to Precision of Atomic Position (Reproduced from D. M. Blow (2002) by permission of Oxford University Press.) 
は上記の Blow による式が最も簡便かつ適切と考え られる。この誤差は回折データの性質を用いて見積 もるため diffraction component precision index (DPI) と呼ばれる。これまでドッキングを行う場合，X 線解析のデー夕は一律に扱われることが多かったが, DPI を求めそれに応じてドッキング結果を解釈す る方が適切である。またドッキングを行うに当た り，標的分子中の原子位置の不確定性の目安である DPI をあらかじめ知っておくことは重要である.

\section{Ph4Dock を用いたドッキング計算の例}

筆者が現在使用しているソフトウェア Ph4Dock を用いたドッキング計算の具体例を説明する。この 例では，インフルエンザ・ウイルスのノイラミニ ダーゼに対する阻害剤 BCX-1812（Fig. 2）という 化合物が，どのようにこの酵素を阻害するかをドッ キングで推定する。実際には，この酵素と阻害剤の 複合体の X 線解析は既に行われているので，どれ だけ実験で求められた構造が正しく予想されるかが 興味のポイントである．概要のところで述べたよう にドッキングは複数の段階に分けて実行する. Ph4Dock はソフトウェア・システム $\mathrm{MOE}^{14)}$ の下 で動くように開発されたものであり，以下のすべて の計算はMOEを用いて行った。

\section{第一段階：標的分子構造の準備之検討 標的分} 子構造には Protein Data Bank の 1L7H ${ }^{15)}$ という構 造を用いた。 $R_{\text {free }}$ が 0.177 であることから，この構 造の X 線解析は良好に行われていると考えられ る。しかし，アスパラギンやグルタミンの酸素原子 と窒素原子の帰属及びヒスチジンのイミダゾール環 の配向とプロトン化状態については，事前に吟味し ておく必要がある。筆者らは，この目的に

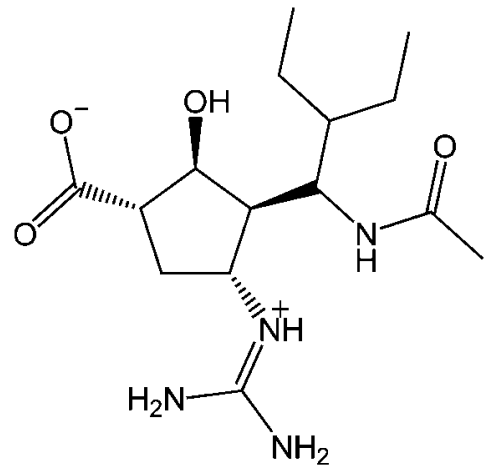

Fig. 2. Chemical Structure of BCX-1812
Reduce ${ }^{16)}$ というソフトウェアを使用している。こ のソフトウェアは，X 線解析では実験的に一意的 に決定できないこれらの構造に対して，それらのア ミノ酸残基周囲の状況を勘案して，妥当な構造を提 案してくれる。しかし，これはあくまで 1 つの提案 であり，決定的ではない，Reduceの結果は，修正 した座標の形で出力されるので，便利である。これ までの筆者の経験では，Reduce による構造修正は 比較的良好である。実際に，1L7H に対して， Reduce による検討を行うと， 7 個のアスパラギン, 2 個のグルタミン及び 1 個のヒスチジンの側鎖を $180^{\circ}$ 回転（フリップ）した方が妥当であると示唆さ れた。 こらの残基については Reduceによる提案が 妥当であるので，採用することにした．さらに 1 個 のヒスチジンについてはフリップしても，依然とし て周囲との相互作用は芳しくないと判断されたので,

$\mathrm{X}$ 線解析者の解釈を尊重して，元の立体配座を残 した.

Reduce では最も妥当な位置に水素原子を発生す るが，一部の水素原子が発生できないので，MOE の分子構築の機能を用いて最終的にすべての水素原 子を幾何学的計算で発生させた。発生した水素原子 の位置を最適なものにするために，水素原子のみを あとで述べる力場計算で最適化した。これで標的分 子構造の準備はできた。

第二段階：阻害剤結合部位の予測と結合部位の特 性解析 結合部位が分からない状況では，標的分 子の表面にあり，阻害剤の結合が可能な部位をまず 探索しなければならない。その目的で，筆者らは MOE の中にある Alpha Site Finder という機能を用 いる．このソフトウェアは，標的分子表面の原子か ら，それらの原子と直接的に相互作用する可能性の ある位置を計算し，その位置を小さい球（これを $\alpha$ 球と呼ぶ）で表現する。またその位置が標的分子か ら受ける影響により，その球を大きく親水的及び疎 水的相互作用を受ける球として表現する。 $\alpha$ 球を近 接して複数個置くことができる空間は，標的分子表 面のくぼみを意味し，リガンド分子の結合部位にな り得る。このような位置を $\alpha$ サイトと呼ぶことに する.

1L7H について求めた 1 つの $\alpha$ サイトの様子を Fig. 3 に示した. 通常複数の $\alpha$ サイトが 1 つの標的 分子に対して求められるが，この Fig. 3 で表示し 


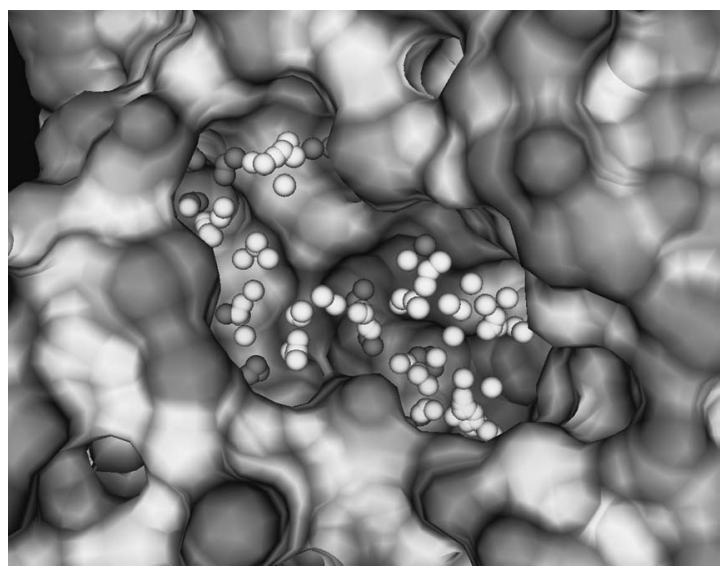

Fig. 3. $\alpha$ Spheres Located in a Cavity of Neuraminidase Grey and white $\alpha$ spheres represent hydrophilic and hydrophobic characters, respectively. The enzyme is shown by a solvent accessible surface.

たのはその中で最も大きいものである．この標的分 子の場合，他のサイトは小さすぎてリガンド分子は 結合できないと判断されたので，事実上 1 つのサイ トが求められた。このサイトにある $\alpha$ 球は標的分 子と強く相互作用するリガンド分子の原子がくる位 置と考えられる。したがって， $\alpha$ 球を頼りにリガン ド分子をドッキングしてもよいが，現実的にはリガ ンド分子の特定の原子団が $\alpha$ サイトの特定領域に 結合すると考えられる. したがって $\alpha$ サイトを各 $\alpha$ 球周囲にある標的分子からの影響により，いくつか の領域(ファーマコフォア)に分けることができる. 例えば，疎水的な領域，正の電荷を帯びた領域，負 の電荷を帯びた領域などである。このような領域に 分けておくと，リガンド分子がこの結合部位にどの ような配向で結合するかをあらかじめ予測できるの で，ドッキングの効率が向上する．Ph4Dock では この方法を採用している. Figure 4 には， $\alpha$ 球をよ り大きな球であるファーマコフォアで表現した様子 を示す。この Fig. 4 をみると, どの領域にリガン ド分子のどのような原子団がくるかを想像できるの で，医薬分子設計者にとっては非常に便利である.

第三段階：リガンド分子の可能な立体配座の発生 第二段階で同定された結合部位に結合できるリガン ド分子がごのような立体配座を取るかは，ドッキン グ前には分からない。 また最も安定な立体配座でリ ガンド分子は標的分子に結合する訳ではない。そこ で，可能な限り多くの立体配座を発生させることが 必要になる。この問題は意外に難しい。Ph4Dock

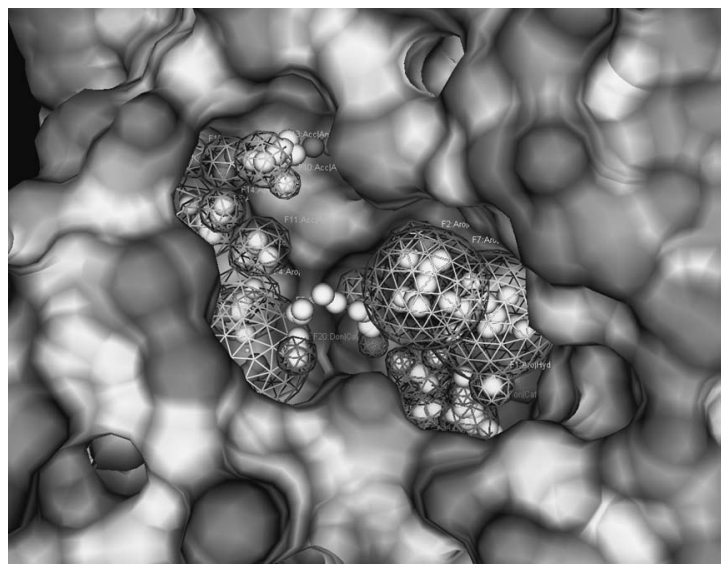

Fig. 4. Pharmacophores are Expressed by Chicken-wire Networks

Small spheres are $\alpha$ spheres.

には立体配座を発生させる複数の方法が用意されて いるが，適切な試行回数を設定すれば確率的な手法 で，十分に立体配座空間を探索することが可能であ る. 必要とされる試行回数は分子内の自由回転可能 な結合の数におおよそ比例すると考えてよい。この 例では 250 個の互いに類似度の低い立体配座を発生 させた。

第四段階：ドッキング計算とその結果の検討 第二段階で求めた結合部位のファーマコフォアと第 三段階で求めたリガンド分子の複数の立体配座を用 いて，ドッキング計算を行う。 大きく分けてこの段 階は 2 つに分けられる，第一はファーマコフォアと 立体配座の一致度を確認することであり，これにパ スしたものが第二段階で分子力場法により最適化さ れる。種々の分子力場が提案されているが, Ph4Dock では MMFF94x ${ }^{17)}$ を採用している.

第二段階で求めた結合部位はかなり広く，その中 で比較的小さな BCX-1812 がどの位置に結合する かは興味深い。通常ドッキング計算では, 複数の結 合様式が計算されるので，答えは唯一ではない。し たがって，それらの中からどれが妥当であるのかを 判断する必要がある。そのため，ドッキング結果を 評価するために種々の評価関数が提案されている. 筆者らは基本的に次式で表されるUtotal で結果を 判断している．本来は自由エネルギー変化を求めた いが，エントロピー項の算出が難しいことなどから， Utotal で判断することにしている.

$U$ total $=U$ ele $+U$ vdw + Uligand 
$U$ ele 及び $U v d w$ はそれぞれ標的分子とリガンド分 子間の静電相互作用及びファン・デル・ワールス相 互作用を示す。Uligand はリガンド分子内のひずみ のエネルギーである。この計算結果では，最低の Utotal は- $18.93 \mathrm{kcal} / \mathrm{mol}$ で，このエネルギーを与 えるドッキング結果が最も妥当な結果と考えられ る。ドッキング計算で予測された BCX-1812 の結 合部位での位置と構造を Fig. 5 に示した。幅の広 い結合部位の片側奥にBCX-1812 は結合すること が予想された。

ドッキングで得られたリガンド分子の結合位置と 構造が，X 線解析で実験的に得られたものをどの 程度再現しているかを知るためによく計算される量 が，対応する非水素原子の「ずれ」の二乗平均の平 方根 (root mean square deviation 略して rmsd) で ある。 rmsd が0であれば，結晶解析で求められた 非水素原子と完全に一致する構造がドッキングで求 められたことになる. rmsd が大きくなればなるほ ど，ドッキング結果と実験結果の一致度は低くなる。 Ph4Dock で得られた BCX-1812 では，rmsd は $0.397 \AA$ となり，結合位置だけでなく，阻害剤の立 体構造まで正確に予測できたことが分かる．Figure 6 にX 線解析で求められた BCX-1812 とドッキン グで得られた構造を重ね合わせたものを示す。両者 は極めて良好に一致している。この例は， Ph4Dock を使えば，X 線解析の結果にかなり近い 構造をドッキングで得ることができることを示す．

\section{5. ドッキング計算はどの程度正確か}

ドッキングに関する多くの論文では蛋白質 X 線

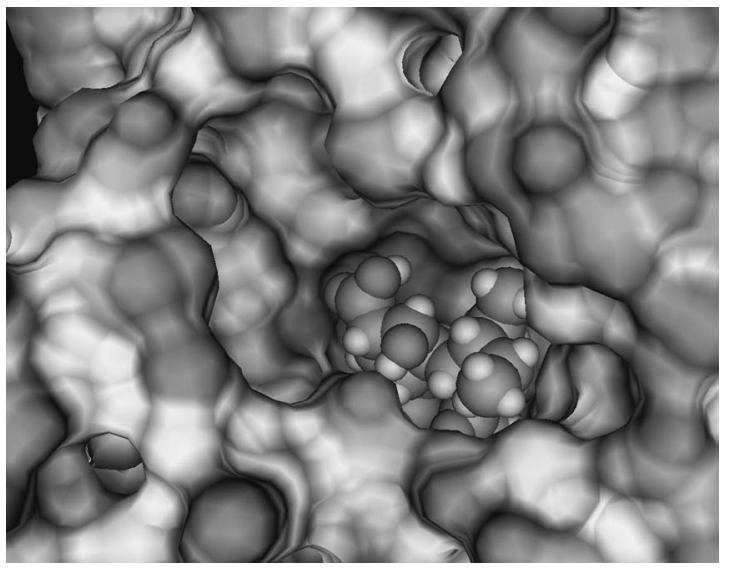

Fig. 5. The Binding Site of BCX-1812 BCX-1812 is depicted by van der Waals radii.
解析の結果とドッキングの結果の $\mathrm{rmsd}$ が $2.0 \AA$ 以 下になったときに，ドッキングは成功したと判断す る。しかし，ドッキングの結果はドッキングに用い る標的分子の X 線解析の精度に依存するで，一律

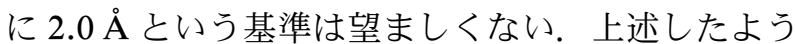
に蛋白質 X 線解析では原子の座標の誤差が求めら れない。そこで筆者らは DPIに基づいて，rmsdの 誤差に相当する量を計算し，それをもってドッキン グの結果を評価することを提案した. ${ }^{7)} \mathrm{rmsd}$ の誤差 は $2 \sqrt{2} D P I$ と見積もることができ，この值を $\mathrm{rmsd}$ の標準偏差と考えれば，ドッキングの結果を評価で きる．先の $1 \mathrm{~L} 7 \mathrm{H}$ の場合，PDB にあるデー夕に基 づけば，DPI は $0.171 \AA$ と計算できる。したがっ て，ドッキングによって得られる構造も本質的に同 じ誤差を持つと仮定すれば，rmsdの誤差は 0.484 ^となる。Utotal が最低であった構造に対する rmsd が $0.397 \AA$ ^であったので，この rmsd はその標 準偏差以下ということになる。つまりドッキングで 得られたリガンド分子の構造は本質的に X 線解析 で得られた構造と同じであることを示す。このよう にDPI を用いれば，標的分子毎にドッキングで得 られた結果をある程度定量的に評価することが可能 である. Figure 6 をみても分かるように, Ph4Dock で BCX-1812 をノイラミニダーゼにドッキングさ せると，ほとんど X 線解析で得た構造と同じ構造 が得られるが，誤差のレベルからも実験に匹敵する 正確さで構造が求められている.

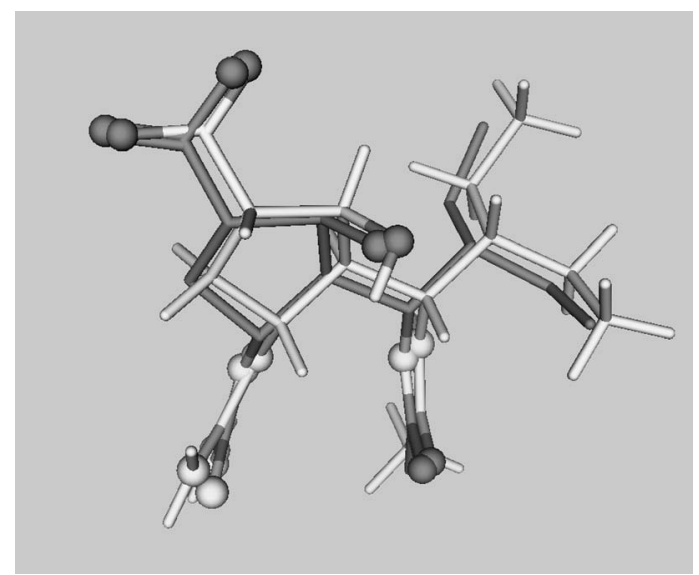

Fig. 6. A Superposition of the Predicted and Experimental Structures of BCX-1812

Oxygen and nitrogen atoms are depicted by small balls. The molecule with dark bonds is the X-ray structure and another molecule is the predicted structure by Ph4Dock. 
1L7H のように, 既に X 線解析で複合体の構造 が分かっている構造を用いて，その構造をドッキン グで再現できるかどうかを再ドッキング（redocking）によって確認することは，使用しているソフ トウェアの性能や特性をチェックしたり，現在使用 している標的分子の特徵を理解する上で極めて重要 である，筆者らは，高質の X 線解析より得られた 標的分子と医薬分子らしい (drug-like) 化合物との 複合体構造 43 種類を用いて, Ph4Dock による再ド ッキング計算を行った. ${ }^{7)}$ その結果を Table 1 に示 す。計算の条件の詳細は省くが，おおよそ前節で用 いた手続きに沿って行った. ドッキング結果のうち, rmsd の值が $3.0 \sigma(D P I)$ より小さい值になつた構造 は 25 あり，全体の $60 \%$ である。.すなわち $60 \%$ の構 造は X 線解析の実験誤差以内で，リガンド分子の 構造と結合位置を予測できたことを意味する。また 一般的な基準より厳格な $\mathrm{rmsd}<1.5 \AA$ の構造を与 えた結果は 34 構造あり，全体の $80 \%$ になる。これ ら 43 種類の複合体を構成する標的分子とリガンド 分子は多様であるが，それらの系に対して Ph4Dock は良好な予測結果を出した。この結果は ドッキング計算の有効性と限界をともに示している が，正確な標的分子の立体構造があれば，少なくと も再ドッキングによるリガンド結合性の予測は十分 可能なことを示唆する.

6. ドッキング法を応用する上での問題点と今後 の課題

筆者らはドッキング法を用いて特定の標的分子に 対する親和性を持った化合物の探索を現在行ってい る.この場合，多くの化合物を含むデータベースを 用いて，それらの化合物のどれが標的分子との結合 性が高いかを予測する．探索の対象とする化合物は 実際に購入可能な化合物でも，仮想的な化合物でも 構わない。ドッキング法はいつたん手続きを確立す れば，多くの可能性を短時間に検証できるという極 めて大きな長所を持っているので, それほど能力の 高いコンピュータでなくとも，1 週間に数万化合物 の探索を行うことも可能である.

ドッキング法を適用する上での大きな問題点は 4 つほどある。

第一の問題点は標的分子の立体構造である．まず 既に述べたように蛋白質 $\mathrm{X}$ 線結晶解析の限界によ る曖昧性があり，この問題はすぐには解決されない
Table 1. Results of Docking Predictions on 43 Complexes $^{a)}$

\begin{tabular}{|c|c|c|c|c|}
\hline PDB code & Resolution $(\AA)$ & $R_{\text {free }}$ & $2 \sqrt{2} \sigma(\AA)^{a)}$ & $\operatorname{rmsd}(\AA)$ \\
\hline $1 \mathrm{~A} 28$ & 1.80 & 0.228 & 0.191 & 0.580 \\
\hline $1 \mathrm{AI} 5$ & 2.36 & 0.222 & 1.137 & 1.238 \\
\hline $1 \mathrm{AQW}$ & 1.80 & 0.261 & 0.447 & 1.165 \\
\hline $1 \mathrm{~B} 58$ & 1.80 & 0.223 & 0.583 & 1.344 \\
\hline $1 \mathrm{~B} 9 \mathrm{~V}$ & 2.35 & 0.271 & 1.321 & $>2.00$ \\
\hline $1 \mathrm{BCU}$ & 2.00 & 0.212 & 0.673 & 0.784 \\
\hline $1 \mathrm{BXO}$ & 0.95 & 0.125 & 0.045 & 1.215 \\
\hline $1 \mathrm{BYG}$ & 2.40 & 0.287 & 1.510 & 1.307 \\
\hline $1 \mathrm{C} 1 \mathrm{E}$ & 1.90 & 0.294 & 0.981 & $>2.00$ \\
\hline $1 \mathrm{C} 5 \mathrm{C}$ & 1.61 & 0.253 & 0.600 & 0.568 \\
\hline $1 \mathrm{C} 5 \mathrm{X}$ & 1.75 & 0.244 & 1.244 & 0.678 \\
\hline $1 C 83$ & 1.80 & 0.231 & 0.501 & 0.793 \\
\hline $1 \mathrm{CBS}$ & 1.80 & 0.237 & 0.617 & 1.019 \\
\hline $1 \mathrm{CKP}$ & 2.05 & 0.260 & 0.939 & 1.167 \\
\hline $1 \mathrm{CVU}$ & 2.40 & 0.235 & 0.896 & 1.000 \\
\hline $1 \mathrm{D} 0 \mathrm{~L}$ & 1.97 & 0.200 & 0.602 & 1.770 \\
\hline 1D3D & 2.04 & 0.223 & 0.814 & $>2.00$ \\
\hline $1 \mathrm{D} 3 \mathrm{H}$ & 1.80 & 0.185 & 0.385 & 1.956 \\
\hline 1D3P & 2.10 & 0.214 & 0.834 & $>2.00$ \\
\hline $1 \mathrm{D} 4 \mathrm{P}$ & 2.07 & 0.231 & 0.877 & 0.713 \\
\hline 1DD7 & 2.25 & 0.284 & 1.307 & 1.209 \\
\hline 1DG5 & 2.00 & 0.243 & 0.735 & 1.125 \\
\hline 1EI1 & 2.30 & 0.266 & 1.394 & 1.381 \\
\hline $1 \mathrm{EJN}$ & 1.80 & 0.240 & 0.696 & 0.905 \\
\hline $1 \mathrm{~F} 0 \mathrm{R}$ & 2.10 & 0.263 & 1.024 & 1.405 \\
\hline $1 \mathrm{~F} 0 \mathrm{~S}$ & 2.10 & 0.263 & 1.007 & 1.533 \\
\hline $1 \mathrm{~F} 3 \mathrm{D}$ & 1.87 & 0.218 & 0.464 & 0.596 \\
\hline 1FL3 & 2.45 & 0.262 & 1.137 & 1.113 \\
\hline $1 \mathrm{KEL}$ & 1.90 & 0.258 & 0.902 & 1.351 \\
\hline $1 \mathrm{LIC}$ & 1.60 & 0.225 & 0.436 & 1.480 \\
\hline 1NGP & 2.40 & 0.250 & 1.162 & 0.837 \\
\hline $1 \mathrm{QCF}$ & 2.00 & 0.257 & 0.834 & 0.556 \\
\hline 1QPE & 2.00 & 0.254 & 0.888 & 1.013 \\
\hline 1QPQ & 2.45 & 0.253 & 0.817 & 0.712 \\
\hline 1WAP & 1.80 & 0.225 & 0.218 & 1.251 \\
\hline $1 \mathrm{YEE}$ & 2.20 & 0.260 & 0.399 & $>2.0$ \\
\hline $25 \mathrm{C} 8$ & 2.00 & 0.292 & 0.922 & $>2.0$ \\
\hline $2 \mathrm{ACK}$ & 2.40 & 0.257 & 1.007 & 0.918 \\
\hline $2 \mathrm{PCP}$ & 2.20 & 0.290 & 1.301 & 0.713 \\
\hline 3ERD & 2.03 & 0.248 & 0.905 & 0.898 \\
\hline 3ERT & 1.90 & 0.262 & 0.690 & 0.774 \\
\hline 4LBD & 2.40 & 0.285 & 1.926 & 0.906 \\
\hline \multirow[t]{2}{*}{ 2RTD } & 1.65 & 0.236 & 0.696 & 1.142 \\
\hline & & & & 0.577 \\
\hline
\end{tabular}

a) $\sigma=\sigma\left(r, B_{\text {avg }}\right)$

が，本稿で述べたように化学的に妥当な構造を考え ることで，この問題はある程度回避できる.

第二の問題点は, 標的分子とリガンド分子の相互 作用の評価である。ほとんどすべてのドッキング法 
が現状では分子力場を用いている，現在使われてい る分子力場はかなり改良されており，先の例にみる ように，多様な複合体構造を再現することができ る。したがって，どの分子力場でもかなり多くの系 に適用が可能であることを意味する。しかし，標的 分子の構造を再現するという意味では，現状の分子 力場は十分であるが，多様な化学構造を持つリガン ド分子に対してはかならずしも十分ではない.

第三の問題点は，リガンド分子結合による標的分 子構造の変化の見積もりである。標的分子は誘導適 合（induced fit）により，リガンド分子に依存して 構造変化を起こすと考えられている。しかし，具体 的な構造変化をどのように起こすかについて詳細に 考察した研究例はほとんどない，筆者らは HIV-1 プロテアーゼとその阻害剂 6 種の複合体構造を再ド ッキングして，この系での誘導適合の考察を行っ

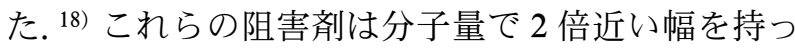
ている．したがって複合体の結合部位も少なからず 誘導適合を受けている. しかしドッキング計算では, 6 種の阻害剂の結合様式を良好に再現することがで きた。このことが一般的に成り立つかどうかは定か ではないが，このような酵素の場合，誘導適合の影 響は一般に予想されるより少ないことが考えられ る. 蛋白質 X 線解析のルーチン化に伴い, 多くの 医薬分子誘導体と標的分子の複合体結晶の構造解析 がなされていると予想されるが，結果が公表されて いるものは非常に少ない。誘導適合に関する研究を さらに進展させる上で，これらのデータ公開が望ま れる。

第四の問題点は，水やイオンの影響である．蛋白 質結晶の中には多くの水が含まれていることは既に 述べた。しかし大部分の水やイオンの運動性は高 く，その位置を X 線解析では確定できない。一方 で X 線解析で明らかにできる，標的分子との相互 作用が強い一部の水やイオンの位置をドッキングの 際にどのように考慮に入れるべきかは難しい問題で ある。いくつかの X 線解析により，特定の水分子 が低分子化合物の結合により，排除されることが分 かっており，これらの水分子は固定的に存在するも のではない，X 線解析で求められた水分子につい て，筆者らはそれを含んだ計算と含まない計算を同 時に行い，それらを比較することを行っている．最 近の筆者らの研究では，少なくとも再ドッキングに
ついては結晶水を考慮した方がずっと成績がよい. イオンの扱いは難しいが，幸いにも医薬分子が結合 する部位において対イオンが結合性に重大な影響を 与える系に筆者らは遭遇していない.

\section{6. 結 語}

本稿ではドッキング法の概要, 実際そして問題点 について概観した．多くの問題点はあるものの，高 質の蛋白質 $\mathrm{X}$ 線構造がかなり容易に得られるよう になってきたこと，Ph4Dock のような強力なアル ゴリズムが登場してきたこと：そしてドッキング計 算を実際に行うコンピュータ能力が向上してきたこ とにより，ドッキングの実用的な応用は既に可能に なったと言っても過言ではない。医薬分子の研究開 発対象とする標的分子の構造的な特徵と低分子化合 物との相互作用の様式を十分に理解して，上記の問 題点を念頭におきながらドッキング法を活用すれば,

HTS に匹敵する効果を生み出すことが可能である と筆者は思う。またドッキング法を応用した研究 は，生体分子間の分子認識の基礎を理解する上でも 非常に重要である. ドッキング法に関する研究が, ともすれば実用的な側面だけを強調され過ぎ，その 基礎科学的な側面が見失われているのは残念であ る.ドッキングの成功率を上げることは，われわれ が分子間相互作用をより正しく評価できることを意 味する。

筆者のドッキング法に関する見方はいささか楽観 的過ぎるかもしれない。しかし，今後の周辺科学の 進展により，この方法は確実に向上し，創薬研究を 強力に推進すると筆者は信じている．分子間相互作 用を原子レベルで把握し，その相互作用を予測す る，というのは分子科学に携わる研究者の大きな目 標であり，夢である.

謝辞 Ph4Dock の開発研究は菱化システム怢 科学技術計算部の片岡良一博士及び後藤純一氏との 共同研究で行われたものである，両氏に深く感謝す る．またこれらの研究を遂行するに当たり，研究費 の援助を得た東海大学総合研究機構及び新エネル ギー・産業技術総合開発機構に深く感謝する.

\section{REFERENCES}

1) Soga S., Shirai H., Kobori M., Hirayama N., Abstracts of papers, the 6th Annual Meeting 
of the Protein Science Society of Japan, Kyoto, April 2006, p. 57.

2) Ewing T. J. A., Makino S., Skillman A. G., Kuntz I. D., J. Comput.-Aided Mol. Des., 15, 411-428 (2001).

3) Rarey M., Kramer B., Lengauer T., Klebe G., J. Mol. Biol., 261, 470-489 (1996).

4) Morris G. M., Goodsell D. S., Halliday R. S., Hey R., Hart W. E, , Belew R. K., Olson A. J., J. Comput. Chem., 19, 1639-1662 (1998) .

5) Jones G., Willett P., Glen R. C., Leach A. R., Taylor R., J. Mol. Biol., 267, 727-748 (1997).

6) Friesner R. A., Banks J. L., Murphy R. B., Halgren T. A., Klicic J. J., Mainz D. T., Repasky M. P., Knoll E. H., Shelley M., Perry J. K., Shaw D. E., Francis P., Shenkin P. S., J. Med. Chem., 47, 1739-1765 (2004).

7) Goto J., Kataoka R., Hirayama N., J. Med. Chem., 47, 6804-6811 (2004).

8) Ramachandran G. N., J. Mol. Biol., 7, 95-99 (1963).

9) Cruickshank D. W. J., Acta Cryst., D44, 583601 (1999).

10) Blow D. M., Acta Cryst., D58, 792-797 (2002).
11) Blow D. M., "Outline of Crystallography for Biologists,"' Oxford University Press, 2002.

12) Bernstein F. C., Koetzle T. F., Williams G. J. B., Meyer F., Bryce M. D., Rogers J. R., Kennard O., Shimanouchi T., Tasumi M., J. Mol. Biol., 112, 535-542 (1997).

13) Luzzati V., Acta Cryst., 5, 802-810 (1952).

14) MOE(Molecular Operating Environment), Version 2004.04, Chemical Computing Group Inc., Montreal, Quebec, Canada, 2004.

15) Smith B. J., Mckimm-Breshkin J. L., Mcdonald M., Fernley R. T., Varghese J. N., Colman P. M., J. Med. Chem., 45, 2207-2215 (2002).

16) Word J. M., Lovell S. C., LaBean T. H., Taylor H. C., Zalis M. E., Presley B. K., Richardson J. S., Richardson D. C., J. Mol. Biol., 285, 1711-1733 (1999).

17) Halgren T. A., J. Comp. Chem., 17, 490-519 (1996).

18) Muta H., Hirayama N., Abstracts of papers, the 126th Annual Meeting of the Pharmaceutical Society of Japan, Sendai, March 2006, P28 [R] pm-137. 